\title{
Apostolat miłosierdzia bł. Edmunda Bojanowskiego w świetle zasady godności człowieka
}

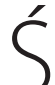
cieżki codzienności życia bł. Edmunda Bojanowskiego wiodą zainteresowanych Ṡ̇yciorysem tego, o którym zwykło się mówić, że był serdecznie dobrym człowiekiem $^{1}$, po niespodziewanych i zmiennych kolejach losu. Pozwalają w Błogosławionym rozeznać Boży zamysł wobec biednych, potrzebujących, zagubionych i bezradnych; zamysł, w którym Bóg posyła człowieka o czułym sercu, głębokiej wierze i niezłomnej woli działania. Taki właśnie człowiek staje się dla potrzebujących narzędziem Bożej łaski i miłosierdzia. Siłą tego misjonarza dobroci jest sam Bóg, potęgą jego miłości jest miłość samego Boga, a głębia spojrzenia na drugiego człowieka znajduje swoją inspirację w spojrzeniu samego Boga na ludzką niedolę.

Prawda ta sprawiła, że Ojciec Święty Jan Paweł II podczas Mszy św. beatyfikacyjnej, mówiąc o Edmundzie Bojanowskim, opisując jego działalność apostolską, użył terminu apostolat miłosierdzia: „Apostolstwo miłosierdzia wypełniło również życie bł. Edmunda Bojanowskiego. Ten wielkopolski ziemianin, obdarowany przez Boga licznymi talentami i szczególną głębią życia duchowego, mimo wątłego zdrowia, z wytrwałością, roztropnością i hojnością serca prowadził i inspirował szeroką działalność na rzecz ludu wiejskiego. Wiedziony pełnym wrażliwości rozeznaniem potrzeb, dał początek licznym dziełom wychowawczym, charytatywnym, kulturalnym i religijnym, które wspierały materialnie i moralnie rodzinę wiejską. Pozostając świeckim człowiekiem, założył dobrze w Polsce znane Zgromadzenie Sióstr Służebniczek Bogarodzicy Dziewicy Niepokalanie

* Ks. DR hab. Ireneusz Stolarczy k, prof. UPJPII, Wydział Teologiczny Sekcja w Tarnowie, Uniwersytet Papieski Jana Pawła II w Krakowie. E-mail: istolarczyk@is.net.pl.

${ }^{1}$ Por. S. Wilk, Wstęp, w: Błogosławiony Edmund Bojanowski. Serdecznie dobry człowiek, red. S. Wilk, Lublin 2000, s. 6. 
Poczętej. We wszelkich działaniach kierował się pragnieniem, by wszyscy ludzie stali się uczestnikami odkupienia. Zapisał się w pamięci ludzkiej jako «serdecznie dobry człowiek», który z miłości do Boga i do człowieka umiał skutecznie jednoczyć różne środowiska wokół dobra. W swej bogatej działalności daleko wyprzedzał to, co na temat apostolstwa świeckich powiedział Sobór Watykański II. Dał wyjątkowy przykład ofiarnej i mądrej pracy dla człowieka, ojczyzny i Kościoła. Dzieło bł. Edmunda Bojanowskiego kontynuują siostry służebniczki, które z całego serca pozdrawiam i dziękuję im za cichą i ofiarną służbę"2.

Apostolat miłosierdzia oznacza istnienie miłości udzielającej się; mówi o realizacji posłania, które ma pełnić miłosierdzie. Taka była duchowość bł. Edmunda. Jest to bowiem duchowość inspirowana wiarą, z której Błogosławiony umiał odczytać wymowne przesłanie o miłości. Miłość rozeznana w krzyżu Chrystusa stała się dla niego imperatywem ukochania Boga i bliźniego. Znamiennym jest, że to właśnie w kulcie Eucharystii znalazł siły do dzieł miłości, a wiara w Opatrzność Bożą pozwoliła w najbardziej zaniedbanym zobaczyć twarz Chrystusa. Oznaczało to skuteczne przeżycie powinności służebnej troski wobec każdego potrzebującego. Błogosławiony potrafił ukochać Chrystusa w drugim człowieku. Ta cenna zdolność wiodła go po drogach życia najbardziej zagubionych i bezradnych. Miał odwagę spotkać się z każdą ludzką słabością, miał pomysł na czynną miłość w sytuacjach, w których inni nie wiedzieli co robić i przestali działać. Podejmował konkretne inicjatywy, które składają się na zdumiewająco owocne i skuteczne dzieło miłosierdzia bł. E. Bojanowskiego. Swoistym testem ich trafności jest z jednej strony skuteczność w udzielaniu pomocy, z drugiej zaś - ponadczasowość. Do dziś pomysł miłosierdzia tej miary jest aktualny i wciąż się rozwija.

Niniejsze opracowanie analizuje apostolat miłosierdzie w kontekście zasady godności człowieka. W pierwszej części przybliża rozumienie zasady godności człowieka, by w dalszej wykazać, że apostolat miłosierdzia skutecznie posłużył do ochrony i rozwoju godności człowieka zarówno w naturalnym, jak i nadprzyrodzonym jej rozumieniu.

\section{Zasada godności człowieka}

Jedną z podstawowych tez myśli społecznej Kościoła jest integralna koncepcja człowieka. Z tak określonej wizji człowieka wynika charakterystyczny dla tego kierunku model życia społecznego. Integralna koncepcja człowieka ukazuje całościową wizję człowieka, opartą na najgłębszej prawdzie o nim samym. Jest

${ }^{2}$ Strona internetowa z dnia 15.09.2017: jan_pawel_ii.opka.org.pl/biblioteka/W/WP/jan_pawel_ii/ podroze/pl-19990613_jp_homilia.html. 
to prawda podkreślająca ostateczne powołanie człowieka ${ }^{3}$, stworzonego na obraz Boży, odkupionego przez Chrystusa i wezwanego do zjednoczenia z Bogiem ${ }^{4}$. Nie ogranicza się ona zatem do wymiaru materialnego i instynktowego, ale sięga dalej - do rzeczywistości wewnętrznej i duchowej, w której dokonuje się osobowe zjednoczenie z Bogiem. Takie ujęcie pozwala z jednej strony docenić świat materii, w którym człowiek tkwi i wzrasta, $\mathrm{z}$ drugiej - uwzględnia bogaty świat ducha, któremu świat materii jest podporządkowany ${ }^{5}$.

Integralna koncepcja człowieka nawiązuje do klasycznej definicji Boecjusza, która głosi, że persona est rationalis naturae individua substantia ${ }^{6}$. Dociekania filozofów, próbujących ująć bogactwo człowieka w sposób wyczerpujący i tłumaczący jego złożoność, pozwoliły mówić o osobie ludzkiej jako o realnej całości, złożonej z ciała i duszy. Tak więc, osoba ludzka, posiadając dwie podstawowe warstwy bytu - cielesno-witalną i duchowo-intelektualną - jest cielesną i duchową całością ${ }^{7}$. Oznacza to, że osoba ludzka, związana przez potrzeby swojego ciała ze światem wegetatywnym, przekracza sferę somatyczną, odchodząc od instynktów i odruchów w kierunku działań świadomych i dobrowolnych. Jako jedyne stworzenie jest w stanie uświadomić sobie swój cel. W duchowej naturze człowieka zawiera się rozum i wolna wola. Dzięki rozumowi osoba ludzka może poznać prawdę, aż do Prawdy Najwyższej włącznie; dzięki wolnej woli może wybrać dobro, aż do Dobra Najwyższego włącznie ${ }^{8}$. Osoba ludzka, jako byt samoistny, jest zdolna do określenia własnych działań. Jest to możliwe dzięki jej duchowym właściwościom - przy pomocy rozumu i wolnej woli. W ten sposób dokonuje się samourzeczywistnianie - rozwój.

Rozwój osoby ludzkiej zakłada dynamiczny charakter natury ludzkiej. W ludzkiej naturze zawarte są cele, które człowiek jest w stanie rozeznać i zrealizować. Jednymi z nich są cele najbliższe, inne - to cele życiowe. Życie realizowane zgodnie z naturą przynosi człowiekowi szczęście. Jest ono związane z realizacją celów wpisanych w ludzką naturę. Jest to proces rozwoju. Proces ten znajduje swoje wypełnienie w zjednoczeniu z Bogiem ${ }^{9}$. Zrealizowanie tego celu łączy się

${ }^{3}$ Jest to cel, który wykracza ponad doczesną rzeczywistość: „Nauka bowiem Chrystusowa łączy niejako ziemię z niebem. Obejmuje ona mianowicie całego człowieka: jego ducha i ciało, rozum i wolę; wzywa go przy tym do wzniesienia myśli ponad zmienne warunki ludzkiego bytowania, ku szczytom życia wyższego, gdzie będzie kiedyś zażywał nieprzemijającego szczęścia i pokoju”, Mater et magistra, nr 2.

${ }^{4}$ Por. J. Majka, Człowiek w encyklikach Jana Pawła II, „Colloquium Salutis” 15 (1983), s. 34.

${ }_{5}^{5}$ Por. S. Lem, O godności ludzkiej (Pojęcie godności w chrześcijaństwie), „W Drodze” 4 (1976), nr 5, s. 29.

${ }^{6}$ Por. I. Dec, Niektóre dawniejsze i współczesne próby rozumienia osoby w „filozofii chrześcijańskiej”, „Communio” 3 (1983), nr 2, s. 105.

7 Por. H. Fahrenbach, Człowiek, „Studia Filozoficzne” 1982, nr 5-6 (198-199), s. 132.

${ }^{8}$ Por. M. A. Krąpiec, Osoba i naród wobec globalizmu, „Człowiek w Kulturze” 2002, nr 14, s. 9.

${ }^{9}$ Por. Z. Zdybicka, Globalizm a religia, „Człowiek w Kulturze” 2002, nr 14, s. 37. 
z faktem, iż oprócz natury człowiek otrzymuje również łaskę, która go uzdalnia do życia w Bogu.

Człowiek odznacza się wyjątkową wartością. Z uwagi na tę wyjątkowość mówimy o godności ludzkiej ${ }^{10}$. Odczucia wyjątkowej godności człowieka znajdują swój wyraz w takich stwierdzeniach o człowieku jak: „najdoskonalszy w całej naturze”, „szczyt hierarchii wszystkich bytów ziemskich”, „korona w dziele Bożego stworzenia”. Można zadać pytanie, skąd wynika ta szczególna godność człowieka. W literaturze społecznego nauczania Kościoła podkreśla się dwa aspekty godności człowieka: przyrodzony i nadprzyrodzony. Pierwszy dotyczy, poruszanej już wyżej, kwestii ludzkiej natury. Wolność i świadomość osoby ludzkiej to dwa przymioty, które pozwalają mówić o godności człowieka $\mathrm{w}$ aspekcie przyrodzonym ${ }^{11}$. Dzięki nim człowiek rozwija się, przeżywa swój dynamizm, samorealizację, samostanowienie i odpowiedzialność za to, co czyni. Drugi aspekt godności dotyczy uczestnictwa człowieka w życiu Boga ${ }^{12}$. Z uwagi na nadprzyrodzony aspekt godności człowieka można powiedzieć, że człowiek został wyniesiony do godności synostwa Bożego, stał się bratem Chrystusa. To właśnie człowiek jest celem Bożego objawienia, do człowieka przemawiał Chrystus, dla niego cierpiał, został skazany na śmierć i zmartwychwstał. Aspekt nadprzyrodzony ludzkiej godności wyraża się również w misji Kościoła Chrystusowego, dla którego właśnie człowiek jest jedyną drogą.

$Z$ tematem godności ludzkiej nierozerwalnie łączy się zagadnienie równości wszystkich ludzi. Równość wynika z takiej samej godności osób ludzkich. Z uwagi na równość godności - tak w aspekcie przyrodzonym, jak i nadprzyrodzonym - mówimy o równości wszystkich ludzi. Nie zaprzecza to jednak różnorodności osób ludzkich. Zróżnicowanie ze względu na tak zwane cechy drugorzędne, na przykład cechy charakteru, zamiłowania, uzdolnienia, talenty, rasy, nie oznacza nierówności w ludzkiej godności ${ }^{13}$. Cechy drugorzędne ubogacają życie społeczne i nigdy nie mogą stać się przyczyną powstawania nierówności społecznych.

Osobie ludzkiej przysługują - z uwagi na godność - niepodważalne prawa, wrodzone, a nie nabyte. Te właśnie prawa, niezbywalne prawa osoby ludzkiej, nie mogą być pod żadnym pozorem naruszane, tak przez innego człowieka, jak i przez określone instytucje społeczne. Godność człowieka wyklucza także jakiekolwiek formy przedmiotowego traktowania osoby ludzkiej. Nigdy i pod żadnym pozorem człowiek nie może być traktowany jako przedmiot, środek

${ }^{10}$ Por. J. Gałkowski, Jan Paweł II o godności człowieka, w: Zagadnienie godności człowieka, red. J. Czerkawski, Lublin 1994, s. 108.

11 Por. M. Gogacz, Godność osoby ludzkiej, „Więź” 17 (1974), nr 6 (194), s. 20.

12 Por. J. Chmiel, Człowiek obrazem Boga, „Znak” 29 (1977), nr 4 (274), s. 365.

13 Por. A. Buchner-Jeziorska, O równości i sprawiedliwości społecznej, „Studia Socjologiczne” 1984, nr 1 (92), s. 184. 
czy narzędzie ${ }^{14}$. Nie może tego czynić inny człowiek, jak również jakakolwiek wspólnota ludzka, nie może to również mieć miejsca w jakiejkolwiek dziedzinie życia społecznego, jak choćby w polityce czy gospodarce.

Prezentując integralną koncepcję człowieka, należy również wspomnieć o społecznym charakterze natury ludzkiej. Katolicka nauka społeczna podkreśla konieczność życia w społeczeństwie. Charakter społeczny ludzkiej natury wyraża się w fakcie, że każdy człowiek, komunikując się z innymi ludźmi, tworzy wartości, które można zrealizować tylko w społecznej współpracy. U podstaw takiego rozumienia życia społecznego znajduje się, poruszona już wcześniej, teza o dynamicznym charakterze ludzkiej natury. O ile bowiem w aspekcie istnienia człowiek jest bytem samodzielnym i doskonałym, o tyle w aspekcie działania jest dynamicznym, zdolnym do rozwoju ${ }^{15}$ i wzrastania w godności. Oczywiście działanie to, polegające na realizacji potencji tkwiącej w ludzkiej naturze, zawsze powinno być zgodne z tą naturą. Zgodność tę wyznacza więc ludzka natura, ostatecznie - Bóg, Stwórca natury.

Potencjalność ludzkiej natury i jej zdolność do zaspokajania potrzeb pozwalają człowiekowi doskonalić się w działaniu. Proces ten dokonuje się tak w wymiarze potrzeb cielesno-witalnych, jak i duchowo-intelektualnych. Nie wszystkie potrzeby mogą być zaspokojone w życiu jednostkowym ${ }^{16}$. Dlatego właśnie człowiek potrzebuje innych ludzi, potrzebuje społeczności, w której - poprzez nawiązanie kontaktu z innymi ludźmi przeżywającymi podobne potrzeby utworzy wspólne wartości, umożliwiające mu pełny rozwój. Oczywiście, należy w tym miejscu podkreślić, że nie każda społeczność jest w stanie sprostać tym oczekiwaniom. Potrzebny jest cały system, określający zestaw praw i obowiązków, dzięki którym każdy człowiek - podmiot i cel życia społecznego - będzie miał równe szanse realizacji swego człowieczeństwa ${ }^{17}$. W społecznym nauczaniu Kościoła określa się tę sytuację stwierdzeniem, iż: „człowiek w całej prawdzie swego istnienia jest i powinien być zasadą, podmiotem i celem wszystkich urządzeń społecznych"18.

O ile integralna koncepcja człowieka opiera się na najgłębszej prawdzie o nim samym, o tyle koncepcje odchodzące od integralnego ujęcia są zawsze odejściem od najgłębszej prawdy o człowieku. Zerwanie z integralną koncepcją człowieka

${ }^{14}$ Por. I. Dec, Osoba jako podmiot w ujęciu kard. Karola Wojtyły, „Collectanea Theologica” 57 (1987), nr 3, s. 6-7.

${ }_{15}$ Por. J. Alfaro, Chrześcijańska wizja postępu ludzkiego, „Chrześcijanin w Świecie” 2 (1970), nr 7, s. 46.

${ }_{16}$ Por. B.G. Błoch, Niektóre aspekty antropologii P. Teilharda de Chardin, „Humanitas” 1986, nr 11, s. 144 .

${ }_{17}$ Por. J. Błachnio, Wartości narodowe w nauczaniu Jana Pawła II o prawdzie i wolności, „Przegląd Religioznawczy" 1995, nr 3 (177), s. 100.

${ }^{18}$ Gaudium et spes, $\mathrm{nr} 25$. 
wyraża się najczęściej w przecenianiu wymiaru materialnego i instynktowego, przy jednoczesnym zamierzonym pominięciu bogactwa sfery wewnętrznej i duchowej. Na takim właśnie gruncie wzrasta konsumizm. Niepełne koncepcje człowieka dotyczą również takich ujęć, w których pozbawia się go prawa do poznania prawdy i możliwości wyboru dobra ${ }^{19}$. Rozum i wola, jako przymioty duchowej natury człowieka, zorientowane są na Najwyższą Prawdę i Najwyższe Dobro. Niepełne koncepcje człowieka są więc w tym wypadku próbą uniemożliwienia poznania Najwyższej Prawdy i wyboru Najwyższego Dobra. Pozostanie na poziomie cząstkowej prawdy i cząstkowego dobra uniemożliwia realizację pełnego dynamizmu natury ludzkiej. Sytuacja taka skazuje tym samym człowieka na konieczność pozostania jedynie na zbyt niskim poziomie osobistego rozwoju.

Odejście od integralnej koncepcji człowieka stwarza również problemy w prawidłowym odczytywaniu i rozumieniu ludzkiej godności. Nie dotyczy to jedynie pozbawienia człowieka jego nadprzyrodzonej godności i pozostawania na poziomie naturalnym ludzkiej godności. Niepełne koncepcje człowieka stwarzają również problemy w samym rozumieniu godności ludzkiej w jej wymiarze przyrodzonym. Błędna interpretacja godności prowadzi do zróżnicowanego traktowania ludzi, odchodząc tym samym od zasady równości. Jest to możliwe wtedy, gdy tak zwane cechy drugorzędne potraktuje się jako pierwszorzędne, tym samym zaś doprowadzi się do stwierdzenia, iż godność człowieka wyraża się w jego cechach charakteru, rasie, płci, talentach.

Niepełne koncepcje człowieka mogą również wyrażać się jako zaprzeczenie naturalnej konieczności życia społecznego. Dotyczy to tych prądów, które widzą w człowieku bardziej indywiduum niż podmiot życia wspólnotowego. Podkreślenie egoizmu, samowystarczalności, wolności i niezależności prowadzi do utworzenia systemu społecznego, w którym życie społeczne pojmowane jest w kategoriach konieczności, jedynie zewnętrznych powiązań i relacji. Dla jednostki egoistycznej społeczeństwo jest ograniczeniem jej wolności i suwerenności o tyle, o ile „drugi” również pragnie żyć na sposób wolny i suwerenny. To błędne zorientowanie na jednostkę - antropocentryzm - wywodzi się ze średniowiecza. Jako przeciwwaga orientacji na Boga - teocentryzm - znalazło rozwinięcie w reformacji, a także w stwierdzeniu społecznego indywidualizmu popierającego tezę, iż człowiek nie potrzebuje życia społecznego ${ }^{20}$. Powstała na tym gruncie teoria umowy społecznej jest zerwaniem $z$ ideą społecznego charakteru natury ludzkiej.

Myśl społeczna Kościoła, zachowując całość integralnej koncepcji człowieka i związanych z nią implikacji społecznych, nie podziela poglądu, iż człowiek jest

${ }_{19}$ Por. W. Chudy, Kłamstwo koncepcja prawdy, człowieka i społeczeństwa, „Przegląd Powszechny” 1990, nr 6, s. 409.

${ }^{20}$ Por. A. Rauscher, Jan Pawet II o prawach człowieka, „Ethos” 6 (1993), nr 21-22, s. 68. 
zatomizowaną, suwerenną jednostką. Nie jest również możliwy do pogodzenia ze społecznym nauczaniem Kościoła pogląd całkowicie przeciwny, postrzegający człowieka jako cząstkę maszyny, podobną do funkcjonującego trybu w całości mechanizmu ${ }^{21}$. Systemy społeczne i gospodarcze, zakładające tak skrajne ujęcia jak liberalizm czy kolektywizm, wykazały ich bezsensowność i szkodliwość. W społecznym nauczaniu Kościoła podkreśla się, że błąd liberalizmu polegał na takiej koncepcji człowieka, która pozwoliła uzasadnić „trafność” konieczności życia społecznego, pojętego na wzór zbioru niczym nie powiązanych ze sobą jednostek ludzkich oraz postrzegać władzę jako jedyny gwarant zabezpieczenia interesu osobistego. W takim ujęciu władza działa poprzez wydawanie nakazów i zakazów oraz wywieranie przymusu i strachu. Liberalizm zakładał też inne rozumienie dobra społecznego - jedynie jako sumę dóbr jednostkowych, wykazywał również bezsensowność istnienia tak zwanych struktur pośrednich. Wytworzona w ten sposób społeczna luka stwarzała podatny grunt do wzrostu systemów totalitarnych.

Równie zgubny dla dobra poszczególnych ludzi okazał się kolektywizm. Miejsce człowieka zajęło społeczeństwo ${ }^{22}$. Oznaczało to, iż człowiek został pozbawiony podmiotowości, zredukowany do roli narzędzia, środka do osiągnięcia jakiegoś celu. Oznaczało to również prymat społeczeństwa wobec jednostki, ponieważ całość jest ważniejsza od części ${ }^{23}$. W praktyce kolektywizm zerwał z poszanowaniem godności człowieka poprzez kolektywną władzę sprawowaną przez ściśle określoną grupę, partię oraz odrzucenie religii i propagowanie ateistycznej wizji człowieka ${ }^{24}$. Zmiany społeczne, szczególnie te związane z odchodzeniem od tendencji ściśle liberalnych i kolektywnych, wykazały konieczność korekty błędnych koncepcji człowieka.

\section{Apostolat miłosierdzia w służbie godności człowieka}

Niniejsza część opracowania jest próbą spojrzenia na apostolat miłosierdzia bł. Edmunda Bojanowskiego pod kątem promocji człowieka: jego niepowtarzalnej wartości, należnego miejsca w życiu społecznym, politycznym, kulturowym i gospodarczym oraz możliwości integralnego rozwoju. Należy zauważyć, że

${ }^{21}$ Por. S. Kowalczyk, Społeczny charakter człowieka jako podstawa dialogu chrześcijańsko-marksistowskiego, „Collectanea Theologica” 41 (1971), nr 1, s. 42.

${ }_{22}$ Por. W. Gumała, Własność i rozwój społeczny (O pierwszym podstawowym prawie socjologii), „Studia Socjologiczne” 1981, nr 4 (83), s. 22.

${ }^{23}$ Por. A. Cypko, Określenie celów rozwoju społecznego: aspekty ogólnospołeczne i jednostkowe, „Studia Socjologiczne” 1980, nr 4 (79), s. 85-86.

${ }^{24}$ Por. P. Arrupe, Czy chrześcijanie moga przyjąć marksistowska analizę społeczeństwa?, „Chrześcijanin w Świecie” 13 (1981), nr 6, s. 149. 
dzieła miłosierdzia, tak hojnie i konkretnie czynione za życia Edmunda, pozwalają stwierdzić, że stały się one niezwykle skutecznym bodźcem wielowymiarowego rozwoju człowieka. Takie ujęcie apostolatu miłosierdzia bł. Edmunda pozwala stwierdzić, że jest on procesem promującym człowieka i szanującym jego godność. Oznacza to, że może być uznany jako niezwykle skuteczny w służbie godności człowieka.

Służebną rolę dzieł miłosierdzia w poszanowaniu godności człowieka można uzasadnić wykazując przydatność tych dzieł w zachowaniu i pomnażaniu dóbr materialnych, czy duchowych. Ponieważ szersze omówienie tego zagadnienia dotyczy bardziej zasady dobra wspólnego wystarczy wspomnieć w tym miejscu choćby to, że dzięki inicjatywom bł. Edmunda dokonuje się relokacja i sumowanie różnego rodzaju dóbr społeczności lokalnych na użytek najbardziej potrzebujących. W ten sposób apostolat miłosierdzia umożliwia - w niespotykanej do tej pory skali - przymnożenie dóbr materialnych i duchowych. Troskę o dobra materialne w zakresie, który gwarantujące godność życia każdemu człowiekowi, była symptomatyczna dla bł. Edmunda: „Edmund spotkał starą, żebrzącą kobietę, zdarzenie tak opisał: proszac o wspomożenie, narzekała coś o zgubionym chlebie, ale tego dobrze nie zrozumiałem i zajęty rozmowa z księżmi nie dałem jej jałmużny, bo miałem tylko kilka srebrników przy sobie. Srebrnik zdawał mi się datkiem za dużym, więc opuściłem sposobność wsparcia staruszki. Bóg przecież pozwolit mi powetować przewinienie. O kilkaset kroków odszedłszy, spostrzegam na drodze kawat chleba leżacy. Poniosłem, pobiegłem za babka $i$ oprócz chleba znalezionego, dałem jej srebrnika, któregom przed chwila dać żałował. Radość babki i jej głośne błogosławieństwo ileż były więcej warte, niźli ten srebrnik i posługa!"25. Bieda i ubóstwo były dla bł. Edmunda imperatywem wiary do zaangażowania w dzieła miłosierdzia: „W ludziach zwracających się do niego o pomoc odczytywał Boże znaki. Przyjście do Grabonoga ubogiej kobiety z dzieckiem w Wigilię Bożego Narodzenia 1854 roku wzbudziło w nim skojarzenie z losem Świętej Rodziny: pisałem w dzienniku. Wtem powiadaja mi najbardziej pożądana przy dzisiejszym dniu wiadomość, że przyszła jakaś nędzna niezmiernie kobieta, dopraszająca się o przyjęcie jej dziecka do sierot. Dziś Wigilia, dziś pamiątka, jak uboga Rodzina Przenajświętsza szukała gospody. Jakież to dziwnie miłe dla serca zdarzenie - pomyślałem sobie - że dziś właśnie uboga wdowa przynosi nam sierotkę do żłobka!"26.

Dobra materialne, których użyteczność w skali mikro staje się możliwa dzięki lokalnym inicjatywom, służą nie tylko małej grupie lokalnej społeczności, ale wszystkim mieszkańcom państwa. Podobny efekt pojawia się w przypadku dóbr duchowych, które - również dzięki lokalnym działaniom - są również

${ }_{25}$ Dobry patron bł. Edmund Bojanowski, red. G. Polak, A. Zelga, Warszawa 2015, s. 24.

26 Tamże, s. 24-25. 
dostępne dla innych ludzi, niezależnie od miejsca zamieszkania czy aktualnego przebywania. Jednym słowem, w okresie działalności bł. Edmunda dochodzi do niespotykanej do tej pory sytuacji, w której każdy człowiek ma możliwość ubogacenia się dorobkiem inicjatyw lokalnych. Jeszcze nigdy tak duża grupa ludzi nie była w stanie korzystać $\mathrm{z}$ tak wielkiej puli dóbr. Jeśli w tym miejscu przypomnimy, że cechą charakterystyczną ludzkiej natury jest zdolność i potrzeba wyboru dobra, to proces apostolatu miłosierdzia jawi się jako skuteczne narzędzie zwiększania możliwości wyboru dobra ${ }^{27}$. Można więc powiedzieć, że apostolat miłosierdzia o tyle wspiera człowieka, o ile zwiększa możliwość wyboru dobra, które gromadzi i do którego zwiększa dostęp w wymiarze szerszych niż lokalne społeczności ${ }^{28}$. Ten, tak bardzo charakterystyczny dla całości zaangażowania bł. E. Bojanowskiego efekt, pozwala stwierdzić, że składa on współczesnemu człowiekowi bogatą ofertę dóbr, co z kolei zwiększa możliwości wyboru. Z tego względu apostolat miłosierdzia może być uznany za proces służący rozwojowi człowieka.

Siłę do realizacji apostolatu miłosierdzia czerpał bł. Edmund $\mathrm{z}$ wiary. Imperatyw pomocy odczytywał z wiary w Opatrzność Bożą. Często o tej prawdzie wspomina w swoich pismach: „O, jakże cudowne są sprawy Opatrzności! Wtenczas kiedyśmy nie wiedzieli skąd dalej wydatki przedsięwziętej budowy opłacić, kiedyśmy tylko o tyle spokojni byli, o ile nasza ufność w Panu Bogu pokrzepiła nas w wytrwałości - zsyła nam Bóg Najmiłosierniejszy pomoc wystarczającą do uskutecznienia tak trudnego w naszym niedostatku przedsięwzięcia"29. W innym zaś miejscu notuje także: „Jakież było moje uszczęśliwienie, gdym przeliczył samymi papierami kasowymi 400 talarów! Podziękowałem nasamprzód Bogu, a potem i kochanego dawcę uściskałem serdecznie. O, jakże to Bóg litościwy pokazuje jawnie, aby w miłosiernych przedsięwzięciach ufać Opatrzności Bożej”30. Nie dziwi więc, że bł. Edmund pragnął, by inni również ufali Opatrzności Bożej: „Prosiłem, aby mi wymalowano Oko Opatrzności ze złoconymi promieniami na tle błękitnym z napisem u spodu: Bóg wszystko widzi. Tablicę tę chcę umieścić w izbie ochronki podrzeckiej nade drzwiami. Zdaje mi się bowiem, że to może mieć dużo wpływu na przebywających w tym domku"31.

Apostolat miłosierdzia można postrzegać również jako narzędzie rozpowszechniania wiedzy. Sam - jak notują to biografowie - miał sposobność rozwoju edukacyjnego: „W 1832 r. wyjeżdża wraz z matką do Wrocławia, gdzie uzupełnia wykształcenie średnie, a jednocześnie studiuje na tamtejszym Uniwersytecie, na Wydziale Nauk Filozoficznych. W roku 1836 przenosi się do Berlina, gdzie kontynuuje studia. Ze względu na pogarszający się stan zdrowia przerywa

27 Por. J. P. Foley, Bóg w globalnej wiosce, Kraków 2002, s. 38-39.

28 Por. J. Krucina, Dobro osoby a dobro wspólne, „Ateneum Kapłańskie” 62 (1970), nr 2 (74), s. 222.

29 Stuga Boży Edmund Bojanowski. Myśli, przeżycia, nauki, opr. Hołda K., Opole 1985, s. 18.

30 Tamże, s. 23.

31 Tamże, s. 47. 
studia i po kuracji w Dusznikach powraca w 1839 do rodzinnego Grabonoga, zamieszkując u przyrodniego brata Teofila Wilkońskiego. Nie zważając na słabe zdrowie, włącza się w działalność społecznikowską w środowisku gostyńskim"32. Troska bł. Edmunda o rozwój oświaty, szczególnie osobiste inicjatywy, stanowią doskonały nośnik informacji naukowej. Upowszechniają dostęp do najnowszych osiągnięć wielu dziedzin nauki, popularyzują zagadnienia dostępne do tej pory jedynie elitarnej grupie zainteresowanych sprawą naukowców. Dzięki dziełom miłosierdzia wiedza staje się dostępna nie tylko w renomowanych uczelniach i bibliotekach. Równe szanse przyswojenia wiedzy ma grono ludzi pozostających w bezpośrednim kontakcie z uczelnią, jak również każdy człowiek - być może bardzo oddalony od miejsca edukacji - który poszukuje rozwiązania interesujących go kwestii. Apostolat miłosierdzia staje się w tym sensie owocnym nośnikiem informacji naukowej, do której mają swobodny dostęp ludzie prości i oddaleni od wyedukowanych elit. Jest to niewątpliwie pozytywne oddziaływanie na poznawcze potrzeby ludzkiej natury. Rozum, poszukujący prawdy, spotyka w dziełach miłosierdzia bogatą propozycję ogólnoludzkich przemyśleń, wniosków i badań naukowych. Różnorodność środowisk naukowych, pozostających poprzez apostolat miłosierdzia w twórczej bliskości, to wielka szansa na wzajemne ich ubogacenie i inspiracje ${ }^{33}$. Ponadto, podobnie jak w przypadku zintegrowanego dobra w skali szerszych środowisk, dokonuje się sumowanie osiągnięć naukowych i wzrost ogólnej wiedzy ${ }^{34}$. Można powiedzieć, że prawda jest coraz bardziej poznawana. Dokonuje się to dzięki możliwościom, jakie stwarza człowiekowi edukacja rozumiana jako dzieło miłosierdzia ${ }^{35}$. W tym właśnie sensie należy postrzegać apostolat miłosierdzia jako jeszcze jedną okazję do tego, by zwiększać szanse rozwoju człowieka z uwagi na jego duchowe potrzeby i możliwościci ${ }^{36}$. Tak więc, dzieła miłosierdzia mogą być nazwane rozwojem i są nimi - w kontekście poszanowania godności ludzkiej - ponieważ stają się skutecznym narzędziem koncentracji wiedzy naukowej i procesem usprawniającym korzystanie z niej.

Z uznaniem należy zauważyć kolejną rolę dzieł apostolatu miłosierdzia w uszanowaniu godności człowieka ${ }^{37}$. Służą one uniwersalnemu systemu ochrony praw człowieka. Dzięki dziełom miłosierdzia zwrócono uwagę na poszczególne

32 A. Pękala, Od pracy organicznej do świętości, w: Błogosławiony Edmund Bojanowski. Serdecznie dobry człowiek, red. S. Wilk, Lublin 2000, s. 22.

${ }_{33}$ Por. T. Ślipko, Imperatyw prawdy w życiu jednostkowym i społecznym, „Chrześcijanin w Świecie" 25 (1993), nr 2, s. 234.

${ }^{34}$ Por. L. Dyczewski, Kształcenie i wychowanie człowieka czynnikiem rozwoju społecznego, „Życie i Myśl - Zeszyty Problemowe” 1995, nr 5, s. 23.

${ }_{35}$ Por. J. Majka, Teleologia rozwoju społecznego, „Chrześcijanin w Świecie” 7 (1975), nr 3, s. 33.

${ }^{36}$ Por. S. Kowalczyk, Koncepcja wolności odpowiedzialnej J. Maritaina, „Colloquium Salutis” 16 (1984), s. 282-283.

${ }^{37}$ Por. F. J. Mazurek, Ochrona praw człowieka przez rozwój, „Roczniki Nauk Społecznych” 14 (1986), nr 1, s. 68. 
społeczności lokalne. Ich sukcesy i porażki nie zamykają się już w kręgu geograficznej ograniczoności. To, czym żyje którakolwiek ze społeczności jest w okresie coraz bardziej znane szerszym społecznościom ${ }^{38}$. Dzieła miłosierdzia uniemożliwiają wytworzenie enklaw zła i braku poszanowania praw człowieka, zupełnie niedostępnych szerszej opinii. To, co bulwersuje opinię małych populacji staje się poprzez apostolat miłosierdzia przedmiotem uwagi szerszych społeczności, rozbudza wielowątkowe dyskusje i zachęca do ogólnopaństwowej obrony uciśnionych i niesprawiedliwie traktowanych. Jakakolwiek lokalna niesprawiedliwość niemal natychmiast staje się za pośrednictwem dzieł miłosierdzia publicznych dyskusji. Można w tym wypadku powiedzieć o dziś niezwykle aktualnej miedialnej sile nacisku. W ten sposób wymowa i przekaz apostolatu miłosierdzia przyczynia się do zrównoważenia poziomu humanizacji życia społecznego, kulturowego, politycznego i gospodarczego w skali szerszych społeczności. Moc oddziaływania mediów w trosce o równe poszanowanie ludzkiej godności, przez zachowanie ludzkich praw, można nazwać sieciowym rozwiązaniem kwestii praw człowieka. W takim znaczeniu apostolat miłosierdzia jawi się jako sprawny system ochrony najcenniejszych wartości ${ }^{39}$, dla utrzymania ładu społecznego w skali każdego środowiska. Ponadto, skuteczność apostolatu miłosierdzia zwrócił uwagę na potrzebę refleksji nad etosem życia społecznego i ładem społecznym. Jest to jeszcze jeden sposób zaangażowania dzieł miłosierdzia do szerzenia sprawdzonych i uznanych wartości, określonych jako prawa trzeciej generacji. Apostolat miłosierdzia jest przedprożem cywilizacji miłości, z pewnością może być uznany jako skuteczny środek rozszerzania zasad cywilizacji miłości ${ }^{40}$. W stopniu, $\mathrm{w}$ jakim to realizuje staje się procesem zmian o charakterze rozwoju.

Pytając o podstawy uznania apostolatu miłosierdzia za proces przemian o charakterze rozwoju należy z pewnością zauważyć kolejną - jak się wydaje bardzo ważną rolę tego procesu w zdynamizowaniu współczesnego człowieka do działania, wymagania od siebie - jednym słowem - do osobowego rozwoju. Proces ten trafnie opisuje jeden z biografów: „Przy całej swojej emanującej na zewnątrz dobroci nie był bynajmniej ugrzecznionym świętoszkiem sączącym wszystkim miód do ucha i przepraszającym za to, że żyje. Miał charakter. Robotnikom, którzy po partacku wykonali swoją pracę, wytknął nieuczciwość, zapłacił mniej niż to było uzgodnione i oświadczył, że u niego nie dostaną już żadnego zatrudnienia. Cieśli, który postawił pokraczną altanę w ogródku, kazał ją rozebrać i zbudować nową"41.

${ }^{38}$ Por. Z. Drozdek, Prawa człowieka a rozwój społeczno-gospodarczy, „Chrześcijanin w Świecie” 10 (1978), nr 3-4, s. 78.

39 Por. A. Dylus, Liberalizm? Tak, ale jaki?, „Przegląd Powszechny” 1995, nr 1, s. 95.

${ }^{40}$ Por. M. Gogacz, Wolność, sprawiedliwość, prawda, miłość - program dla Polski, „Roczniki Filozoficzne" 39/40 (1991/1992), nr 1, s. 199-200.

${ }^{41}$ Dobry patron bł. Edmund Bojanowski, red. G. Polak, A. Zelga, s. 25-26. 
Apostolat miłosierdzia bł. E. Bojanowskiego stawiał współczesnemu człowiekowi szereg nowych, niejednokrotnie bardzo trudnych wyzwań. Dlatego też dzieła miłosierdzia to bardzo efektywny proces odnowy ludzkiej godności, służący poszanowaniu niepowtarzalnej wartości osoby ludzkiej. Z pewnością, proponując szereg nowości, obliguje do kreatywnego zachowania. Można powiedzieć, że z jednej strony destabilizuje, z drugiej zaś domaga się zaradności i mądrego dostosowania; a więc jest to destabilizacja w kierunku kreatywnej działalności ${ }^{42}$. Ta swoista akceleracja osobowego rozwoju człowieka inicjowana apostolatem miłosierdzia ma negatywny i pozytywny charakter. W sensie negatywnym można tu mówić o swoistej lekcji, jakiej udziela każde dzieło miłosierdzia, konfrontując i opisując błędy ludzi czy społeczności. Jest to uczenie się na własnych i cudzych błędach, których obecność obnaża każdy czyn miłosierny. Dzięki temu konkretni ludzie i całe społeczności mogą uniknąć tego, co utrudziło innych, a co zostało uświadomione dzięki dobroci czynów miłosiernych.

Akceleracja rozwoju człowieka inicjowana apostolatem miłosierdzia to w znaczeniu pozytywnym - wzrost wyzwań, którym powinien sprostać człowiek okresu bł. E. Bojanowskiego. Wzrasta zapotrzebowanie na ludzką fachowość, biegłość w zawodowych sprawach, a także moralną prawość w działaniu ${ }^{43}$. Konkurencja na rynku gospodarczym, w świecie pracy i w życiu politycznym coraz bardziej uzmysławia, że należy zdobyć wysokie wykształcenie, cechować się nienagannością życia i sumiennością postępowania. Świadomość wysokich wymagań w kontekście czynów miłosierdzia staje się motywem do osobistej troski o rozwój talentów i możliwości, by zachować się na miarę dobra, które zwiera w sobie każdy czyn apostolatu miłosierdzia. W procesie osobistego rozwoju apostolat miłosierdzia staje się nie tylko argumentem do działania, ale jest również narzędziem kształcenia - co zostało już omówione w powyższej części opracowania. Z uwagi na wpływ dzieł miłosierdzia na proces intensyfikacji osobowego rozwoju ówczesnego człowieka można uznać, że proces ten - choć niekiedy stawia bardzo wysokie wymagania - sprzyja wzrostowi człowieka w jego godności.

Zasługi apostolatu miłosierdzia w zachowaniu godności człowieka można zauważyć również w zakresie możliwości, jakie stwarza ten proces w sferze międzyludzkich kontaktów. Świat, zmieniony przez dążenia do budowania większych społeczności, jest niewątpliwie światem wielkich społeczności ${ }^{44}$. Zwiększona liczba uczestników życia społecznego jest jednoczesnym zwiększeniem między-

${ }^{42}$ Por. R. Ingarden, Książeczka o człowieku, Kraków 1998, s. 25.

${ }^{43}$ Por. B. Gaziński, Ład moralny a ład społeczno-gospodarczy, „Chrześcijanin w Świecie” 15 (1983), nr 5, s. 55-56.

${ }^{44}$ Por. J. Majka, Moralne podstawy międzynarodowej współpracy społeczno-gospodarczej i kulturalnej w świetle encykliki „Mater et Magistra”, „Zeszyty Naukowe Katolickiego Uniwersytetu Lubelskiego" 6 (1963), nr 3 (23), s. 7. 
ludzkich styczności. Kontakty między ludźmi nasilają się, ich częstotliwość się zwiększa, zwiększa się również zapotrzebowanie na usprawnienie kontaktów między większą niż dotychczas grupą. Apostolat miłosierdzia otwiera na drugiego człowieka, zapewnia modyfikację międzyludzkich relacji, przełamanie paraliżu informacyjnego i komunikacyjnego. Istnieje skuteczniejsza możliwość dotarcia do licznej grupy rozmówców - choćby dzięki wspólnemu podjęciu dzieł miłosierdzia; dzieł, które angażuje większą grupę ludzi. Z jednej strony otwierają - poprzez zespolenie w działaniu - one ludzi na siebie, stając się często jedyną możliwości podjęcia jakiegokolwiek dialogu $\mathrm{u}^{45}$. A postolat miłosierdzia daje okazję wytworzenia międzyludzkiej komunikacji i jest niejednokrotnie jedyną możliwością - chociaż niedoskonałą to jednak lepszą niż żadna - uzmysłowienia jedności ludzi w każdej skali życia społecznego ${ }^{46}$. W tym sensie apostolat miłosierdzia jawi się jako proces zmian sprzyjających zachowaniu społecznego charakteru ludzkiej natury.

\section{Bibliografia:}

Alfaro J, Chrześcijańska wizja postępu ludzkiego, „Chrześcijanin w Świecie” 2 (1970), nr 7, s. 37-54.

Arrupe P, Czy chrześcijanie moga przyjąć marksistowskq analizę społeczeństwa?, "Chrześcijanin w Świecie" 13 (1981), nr 6, s. 141-154.

Błachnio J, Wartości narodowe w nauczaniu Jana Pawła Il o prawdzie i wolności, „Przegląd Religioznawczy" 1995, nr 3 (177), s. 97-106.

Błoch B. G, Niektóre aspekty antropologii P. Teilharda de Chardin „ "Humanitas” 1986, nr 11, s. 139-164.

Buchner-Jeziorska A, O równości i sprawiedliwości społecznej, „Studia Socjologiczne” 1984, nr 1 (92), s. 179-191.

Chmiel J, Człowiek obrazem Boga, "Znak” 29 (1977), nr 4 (274), s. 363-370.

Chudy W, Kłamstwo koncepcja prawdy, człowieka i społeczeństwa, „Przegląd Powszechny” 1990, nr 6, s. 393-410.

Cypko A, Określenie celów rozwoju społecznego: aspekty ogólnospołeczne i jednostkowe, „Studia Socjologiczne" 1980, nr 4 (79), s. 65-86.

Dec l, Niektóre dawniejsze i współczesne próby rozumienia osoby w "filozofii chrześcijańskiej”, "Communio" 3 (1983), nr 2, s. 103-121.

Dec I, Osoba jako podmiot w ujęciu kard. Karola Wojtyły, "Collectanea Theologica” 57 (1987), nr 3, s. 5-18.

Dobry patron bł. Edmund Bojanowski, red. G. Polak, A. Zelga, Warszawa 2015.

Drozdek Z, Prawa człowieka a rozwój społeczno-gospodarczy , "Chrześcijanin w Świecie” 10 (1978), nr 3-4, s. 77-80.

Dyczewski L, Kształcenie i wychowanie człowieka czynnikiem rozwoju społecznego, „Życie i Myśl Zeszyty Problemowe" 1995, nr 5, s. 22-32.

Dylus A, Liberalizm? Tak, ale jaki?, "Przegląd Powszechny” 1995, nr 1, s. 91-96.

Fahrenbach H, Człowiek, „Studia Filozoficzne” 1982, nr 5-6 (198-199), s. 125-147.

Foley J. P, Bóg w globalnej wiosce, Kraków 2002.

${ }^{45}$ Por. J. Niklewski, O. Świątkiewicz, Sesja naukowa: Społeczeństwo informacyjne - mit czy rzeczywistość, „Prakseologia” 1989, nr 1-2, s. 296.

${ }^{46}$ Por. J. Krucina, Naturalne predyspozycje życia społecznego, „Colloquium Salutis” 1969 s. 166. 
Gałkowski J, Jan Paweł ll o godności człowieka, w: Zagadnienie godności człowieka, red. J. Czerkawski, Lublin 1994, s. 103-112.

Gaudium et spes.

Gaziński B, Ład moralny a ład społeczno-gospodarczy , "Chrześcijanin w Świecie” 15 (1983), nr 5, s. $49-60$.

Gogacz M, Godność osoby ludzkiej, „Więź" 17 (1974), nr 6 (194), s. 11-32.

Gogacz M, Wolność, sprawiedliwość, prawda, miłość - program dla Polski, „Roczniki Filozoficzne” 39/40 (1991/1992), nr 1, s. 193-204.

Gumała W, Własność i rozwój społeczny (O pierwszym podstawowym prawie socjologii), "Studia Socjologiczne" 1981, nr 4 (83), s. 17-28.

Ingarden R, Ksiq̨żeczka o człowieku, Kraków 1998.

Jan XXIII, Mater et magistra.

Kowalczyk S, Koncepcja wolności odpowiedzialnej J. Maritaina, "Colloquium Salutis” 16 (1984), s. 279-291.

Kowalczyk S, Społeczny charakter człowieka jako podstawa dialogu chrześcijańsko-marksistowskiego, "Collectanea Theologica" 41 (1971), nr 1, s. 39-52.

Krąpiec M. A, Osoba i naród wobec globalizmu, "Człowiek w Kulturze” 2002, nr 14, s. 3-16.

Krucina J, Dobro osoby a dobro wspólne, „Ateneum Kapłańskie” 62 (1970), nr 2 (74), s. 218-231.

Krucina J, Naturalne predyspozycje życia społecznego, "Colloquium Salutis" 1969 s. 165-171.

Lem S, O godności ludzkiej (Pojęcie godności w chrześcijaństwie), „W Drodze” 4 (1976), nr 5, s. 24-30.

Majka J, Człowiek w encyklikach Jana Pawła II, "Colloquium Salutis" 15 (1983), s. 33-48.

Majka J, Moralne podstawy międzynarodowej współpracy społeczno-gospodarczej i kulturalnej w świetle encykliki "Mater et Magistra", "Zeszyty Naukowe Katolickiego Uniwersytetu Lubelskiego" 6 (1963), nr 3 (23), s. 3-14.

Majka J, Teleologia rozwoju społecznego, "Chrześcijanin w Świecie” 7 (1975), nr 3, s. 27-45.

Mazurek F. J, Ochrona praw człowieka przez rozwój, „Roczniki Nauk Społecznych” 14 (1986), nr 1, s. 61-79.

Niklewski J, Świątkiewicz O, Sesja naukowa: Społeczeństwo informacyjne - mit czy rzeczywistość, „Prakseologia" 1989, nr 1-2, s. 293-299.

Pękala A, Od pracy organicznej do świętości, w: Błogosławiony Edmund Bojanowski. Serdecznie dobry człowiek, red. S. Wilk, Lublin 2000, s. 21-48.

Rauscher A, Jan Paweł Il o prawach człowieka, „Ethos” 6 (1993), nr 21-22, s. 64-80.

Sługa Boży Edmund Bojanowski. Myśli, przeżycia, nauki, opr. Hołda K., Opole 1985.

Ślipko T, Imperatyw prawdy w życiu jednostkowym i społecznym, "Chrześcijanin w Świecie" 25 (1993), nr 2, s. 231-243.

Wilk S, Wstęp, w: Błogosławiony Edmund Bojanowski. Serdecznie dobry człowiek, red. S. Wilk, Lublin 2000, s. 5-7.

Zdybicka Z, Globalizm a religia, "Człowiek w Kulturze” 2002, nr 14, s. 31-41.

\section{Streszczenie}

Apostolat miłosierdzia bł. Edmunda Bojanowskiego to dzieło miłości przekraczające ramy czasowe okresu życia Błogosławionego. Ponadczasowość dzieł miłosierdzia sprawia, że do dzisiaj jego spojrzenie na bliźniego, uwzględniające troskę o każdego człowieka i skuteczne zaangażowanie się w rozwój całego człowieka jest motywem wielu inicjatyw apostolskich. Bł. Edmund Bojanowski potrafił zobaczyć Chrystusa w drugim człowieku; potrafił też kochać Chrystusa w drugim człowieku. Wszystko to stało się siłą ponadczasowości jego inicjatyw niesienia pomocy bliźniemu poprzez bogactwo dzieł miłosierdzia. Niniejsze opracowanie ukazuje dzieła miłosierdzia tego Błogosławionego jako działalność służebną wobec poszanowania godności każdego człowieka i całego człowieka. 
Pierwsza część przybliża rozumienie zasady godności człowieka w wymiarze nadprzyrodzonym i naturalnym. W drugiej części wykazano ponadczasową skuteczność dzieł miłosierdzia bł. Edmunda w zachowaniu i przywracaniu godności życia każdego człowieka. Należy zauważyć, że owocność dzieł apostolatu miłosierdzia to istotny przyczynek do budowania ogólnospołecznego ładu.

Słowa klucze: miłosierdzie, apostolat miłosierdzia, godność człowieka, zasada godności człowieka, ład społeczny, bł. Edmund Bojanowski.

\section{The apostolate of mercy of Blessed Edmund Bojanowski in the light of the principle of human dignity}

\section{Summary}

The apostolate of mercy of Blessed Edmund Bojanowski is a work of love outside the time period of the life of the Blessed. Timelessness of works of mercy makes that till nowadays his look at the other people, taking into account the concern of every man and effective participation in the development of the whole man is the theme of many apostolic initiatives. Blessed E. Bojanowski was able to see Christ in another man; he could also love Christ in another man. All this has become the force of timelessness of his initiatives to help others through the richness of works of mercy. This work shows the works of mercy of the Blessed as an act of service to respect the dignity of each and every human being. The first part introduces the understanding of the principle of human dignity in a supernatural and natural dimension. The second part shows the timeless efficacy of the works of mercy of Blessed Edmund in preserving and restoring the dignity of every person's life. It should be noted that the fruitfulness of the works of the apostolate of mercy is an important contribution to building a social order.

Keywords: Mercy, apostolate of mercy, human dignity, principle of human dignity, social order, bl. Edmund Bojanowski. 